\title{
A GROUP WORK PROGRAMME TO SUPPORT AND EMPOWER NON-PROFESSIONAL CAREGIVERS OF PEOPLE LIVING WITH AIDS
}

\author{
Dr Corinne Strydom \\ $\mathrm{PhD}$ \\ Lecturer, Social Work, School for Psycho-Social Behavioural Sciences, Potchefstroom Campus of the North-West \\ University \\ Corresponding author: Corinne.Strydom@nwu.ac.za
}

\section{Dr CC Wessels}

$\mathrm{PhD}$

Senior Lecturer, Social Work, School for Psycho-Social Behavioural Sciences, Potchefstroom Campus of the NorthWest University

Keywords: people living with AIDS; empower; group work; non-professional caregivers; support

\section{ABSTRACT}

According to a literature study and a research survey conducted in 2004, caregivers are increasingly forced to deal with people living with AIDS as health services are unable to cope with the fast-growing HIVIAIDS epidemic. Caring for an individual with AIDS-related disease is usually time-consuming, burdensome and stressful. There is also evidence of increased susceptibility to physical health problems, emotional distress and psychiatric disturbances amongst caregivers. There are a number of strategies that should be employed to ensure that caregivers are encouraged to do their work to the best of their ability, without them having to sacrifice their health, family life and own needs. One of the strategies that could help in this regard is the presentation of a group work programme. A programme was presented to 14 female caregivers from a church in a disadvantaged community. The group met for eight consecutive weeks. During the two-hour sessions various topics, including self-knowledge, self-esteem, communication, conflict handling, roles of caregivers, and relationships with the person living with AIDS, were discussed. The group members were subjected to measurement by means of the single system. According to this measurement and an evaluation questionnaire, the programme did succeed in supporting and empowering them as caregivers.

\section{OPSOMMING}

Volgens 'n literatuurstudie en ' $n$ empiriese ondersoek wat in 2004 onderneem is, word versorgers toenemend onder druk geplaas om met mense wat met VIGS lewe te werk, omdat die gesondheidsdienste nie meer die groeiende MIVIVIGS epidemie kan hanteer nie. Om ' $n$ individu met ' $n$ VIGS-verwante siekte te versorg is baie tydrowend, moeisaam en spanningsvol. Daar is ook tekens van verhoogde vatbaarheid vir fisiese gesondheidsprobleme, emosionele spanning, en psigiatriese steurnisse onder versorgers. Daar is ' $n$ aantal strategieë wat aangewend kan word om te verseker dat versorgers aangemoedig word om hulle werk tot die beste van hulle vermoëns te doen, sonder om hulle eie gesondheid, gesinslewe en eie behoeftes onder geskik te stel. Een van die strategieë wat in hierdie opsig kan help is die aanbieding van 'n groepwerkprogram. 'n Program is aan 14 vroulike versorgers van ' $n$ kerk in 'n behoeftige gemeenskap aangebied. Die groep het vir agt agtereenvolgende weke ontmoet. Tydens die twee-uurlange sessies is die volgende onderwerpe bespreek: selfkennis, selfbeeld, kommunikasie, konflikhantering, rolle van die versorgers en die verhoudings met die persoon wat met VIGS lewe. Die groeplede is onderwerp aan meting deur middel van die enkel stelsel. Volgens hierdie metings en die evalueringsvraelyste, het die program daarin geslaag om die versorgers te ondersteun en te bemagtig. 


\section{PROBLEM STATEMENT}

Today, South Africa has one of the fastest-growing HIV epidemics in the world, with an estimated 4.7 million people believed to be infected (Department of Health, 2002:1; Skweyiya, 2003:1). The presence of the debilitating disease, linked with poverty, hinders sustainable development (Baleta, 2002:699) and renders communities vulnerable (National Research Foundation, 2004).

As the epidemic spreads, overwhelming the capacity of the health services to cope, the responsibility of care for people living with AIDS is increasingly borne by family and community members. At the end of life, many individuals also desire the dignity of staying at home to receive care (or to die) and may also wish to avoid the costs of hospitalisation or other institutionalisation (Grabbe \& Demi, 1995:347). According to GoicoecheaBalbona (1998:61), health care utilisation and community support are of the utmost importance in minimising the socio-medical problems of people living with HIV/ AIDS. The backbone of community care programmes for people living with AIDS is non-professional caregivers. These are people, mostly female, who are prepared to care for sick people on a permanent basis. They are not well educated and have not received formal education. They are trained to recognise health problems, to know which conditions they can treat themselves and which need to be referred. They are also taught to give basic nursing care to bedridden clients, to provide emotional support to the clients and families, to give practical advice about nutrition and hygiene and to help with domestic chores. Usually they are supervised by a church or charity organisation and receive very little remuneration (UNAIDS, 2000:16-19).

The HIV epidemic has transformed the face of caregivers (Mullan, 1998:713). The strains on those caring for people living with AIDS are enormous. Caring for an individual with AIDS-related disease is usually time-consuming, burdensome, and unpredictable (Ross, 2001:22). Furthermore, it is a condition that stigmatises not only infected individuals but very often uninfected people working in the field too (Hunt, 1996:299). According to Bebbington and Gatter (1994:575), the work is often on a one-on-one basis with very ill people and this requires considerable commitment. The quality of care they provide and their ability to do so over a sustained period, depend on the protection of their own well-being and morale. O'Connor (2002:38) feels that caregivers can be seen as key providers of care in the health system, but although this is well recognised in principle, care for the carers is rarely given the priority it deserves (UNAIDS, 2000:5).

Research has clearly demonstrated that care-giving is stressful as evidenced by increased susceptibility to physical health problems as well as varying degrees of emotional distress and psychiatric disturbances (Schulz, O'Brien, Bookwala \& Fleissner, 1995:771-791; Schulz, Visintainer \& Williamson, 1990:181-191). According to Arno, Levine and Memmott (1999:185), caregiving may not only strain individual and family resources of the caregiver, but may also increase the caregiver's risk of poor health, family destabilisation and impoverishment. Stress among caregivers in the field of AIDS manifests itself in a wide range of signs and symptoms - psychological, behavioural and physical. Typically they include loss of interest in and commitment to work, feelings of inadequacy, guilt, loss of confidence and self-esteem, difficulty in getting along with people, sleeplessness, excessive fatigue, and depression.

AIDS is often concentrated among the very poor. It is extremely stressful for carers to witness the struggle of families to meet their most basic needs. The stress is often compounded by the fact that the carers themselves are in a similar position. It is common for them to spend all day in the field visiting clients without anything to eat or drink, because they receive small allowances. Caregivers frequently mention lack of money for transport to visit sick clients, or to fetch drugs, or buy paper and pens for record-keeping, or rubber gloves for handling sick clients, as a principal cause of stress. It undermines their ability to do their work and makes them feel inadequate. Sometimes their own families are resentful of the fact that they are working hard for little money.

Besides the preoccupation with personal hardship, the dependence of AIDS programmes on their donors is a constant background source of stress to many carers. A common feeling among carers is that pressure to achieve certain targets or population coverage comes primarily from donors, and failure to achieve them may cause the donors to withdraw support for the programme (UNAIDS, 2000:29). 
There are a few strategies that should be employed to ensure that caregivers are encouraged to do their work to the best of their ability. The first requirement is to formally acknowledge the fact that their work is inherently stressful and that feelings of stress are legitimate and not signs of personal weakness or lack of professionalism. Knowledge is empowering, which means that it gives people confidence, control and choices in life, and it has lasting value (UNAIDS, 2000:7). Caregivers want accurate and complete information that is central to carrying out the caregiver role, because this helps them to feel more confident and enables them to provide better care. It is, however, important to note that caregivers do not perceive information alone as empowering. Information is only perceived to be empowering when it takes into account the preferences, hopes and needs of persons living with AIDS and caregivers (Anon, 2002:142). Thus training plays a central role in the management of stress. For the sake of their morale and self-confidence, carers need to know that their work is recognised and valued. Without assistance, caregivers may put their own health and well-being at risk and jeopardise the care that they are providing (O'Connor, 2002:38).

A literature study on caregivers (Bebbington \& Gatter, 1994:571-586; Evian, 2000:30-60; Goicoechea-Balbona, 1998:61-70; Mullan, 1998:712-739; Ross, 2001:20-32; UNAIDS, 2000:13-39; UNAIDS, 2002:14, 20-25; Whiteside \& Sunter, 2000:137-146) confirmed that caregivers were in dire need of support and help. The following question is asked: 'What is the best way in which caregivers can be supported and empowered?' The New English Usage Dictionary (1995:884) defines support as "to give encouragement, to lend assistance, to give strength, to help and to supply with necessaries", while Staples (1990:3) defines empowerment as "the ongoing capacity of individuals or groups to act on their own behalf to achieve a greater measure of control over their lives and destinies". According to Gutierrez (1990:150) and Lee (1994:30), the empowerment approach aims to help people develop a sense of shared fate with similar others in a small group, to use their strengths as a resource, to critically evaluate the stressful conditions in which they find themselves, to become active change agents and to build capacity through coalitions in order to effect change.

Support groups are fast becoming the intervention of choice in dealing with the challenges associated with care-giving. Group interventions are financially viable and are seen as having the potential to reduce isolation while simultaneously providing a forum for receiving information and support from others. As a result, they are conceptualised as holding the potential to prevent the burden of care-giving from overwhelming the personal resources of the caregivers (Peak, Toseland \& Banks, 1995:440). Therefore it was decided to utilise social group work to address the problems caregivers were faced with.

\section{AIM AND OBJECTIVES OF THE RE- SEARCH}

The aim of the research was to support and empower caregivers by means of a social group work programme.

The research had the following objectives:

- to do a literature and empirical study on the needs and problems of caregivers;

- to develop and present a group work programme to support and empower caregivers;

- $\quad$ to help caregivers to manage stress;and

- to evaluate the effectiveness of the programme.

\section{THEORETICAL ASSUMPTION}

By means of a group work programme during which knowledge and skills are acquired, AIDS caregivers are empowered to meet the challenges of their calling and will be less plagued by stress.

\section{RESEARCH METHODOLOGY}

The design of this study was of an exploratory nature (Babbie, 2001:91-93; Neuman, 2000:21). Although much research has been done on caregivers, there is limited literature on group work with caregivers.

Before any group work programme could be compiled, a thorough investigation had to be launched with regard to the needs and problems experienced by the group members (Garvin, 1997:128). Survey research and specifically the group administered questionnaire were utilised. A questionnaire containing open and closed ended questions was developed by the researchers, and completed before the programme was pre- 
sented.

In order to evaluate the group work programme a single system (the A-B-A-procedure) was used with the same measurement package before the group commenced and at the last meeting (Bloom, Fischer \& Orme, 1999:57; De Vos, Strydom, Fouché \& Delport, 2005:144-147). After studying applicable scales from the WALMYR Assessment Scales Package (Bloom et al. 1999:218225), measuring instruments used in the Social Work Skills Workbook (Cournoyer, 1996:25-40), the researchers found that the scales were unsuitable and designed their own evaluation scales. The members also had to complete an evaluation questionnaire at the last meeting.

In this investigation, the participants were all the caregivers from the Baptist Church in Ikageng, Potchefstroom, numbering fourteen. Inferential statistical analysis could not be used because this was an available sample and not a random sample. Therefore Cohen's ä values were calculated to determine effect sizes to see whether the programme made any practical impact (Cohen, 1988:20-27).

\section{NEEDS ASSESSMENT OF CAREGIVERS}

Before the programme could be designed a needs assessment was done. It was important to establish the needs of the caregivers, because they were from a disadvantaged community and could thus have different needs than caregivers from a more affluent area. The caregivers were asked about the needs and problems that they wanted to be helped with. The answers that were obtained are shown in Table 1.

From this needs assessment, it is obvious that the caregivers had all the above-mentioned needs. To communicate better with the person living with AIDS and his/her family, to communicate better with their own family, to handle conflict situations, to be better informed on AIDS issues and to have a support group, were mentioned as urgent needs.

The caregivers had to respond to what problems they could be experiencing. An indication of their problems is given in Table 2 .
From the results in Table 2, it is obvious that the greatest problems are insufficient support pertaining to health care facilities, depression and insufficient income. Inadequate equipment for caring for people living with AIDS and transport difficulties were also high on the list.

With these results in mind a social group work programme was developed. Attention will first be given to the definition of group work, then to the administrative aspects, the group work process, the aims of the programme and the content of the programme. The evaluation of the programme will then be discussed.

\section{DEFINITION OF SOCIAL GROUP WORK}

Social group work can be defined as a goal-directed activity with small groups aimed at meeting socio-emotional needs and accomplishing tasks. This activity is directed to individual members of a group and to the group as a whole within a system of service delivery (Toseland \& Rivas, 2005:12). In other words, social group work is a method used by the social worker to apply the group process, mutual relationships and programme media in such a way that a group of caregivers can be supported and empowered.

\section{ADMINISTRATIVE ASPECTS OF THE GROUP WORK}

The group was homogeneous with regard to gender, race, scholastic achievement and background. They were Black women who attended school until grade 10 or 12 and worked as caregivers in a disadvantaged community. They also received the same incentives for their work. These similarities of the members lead to a great degree of cohesion, which in turn allowed for an open and intense exploration of their life crises (Corey \& Corey, 2002:107). The group was heterogeneous with regard to age (the mean age being 28 ) and marital status (only three members were married).

The group met on Monday mornings at nine o'clock for eight consecutive weeks. The sessions lasted for about two hours in order to provide enough time for the opening, ice-breaker, discussion, group activity, evaluation and refreshments. According to Corey and Corey (2002:108), a two-hour weekly session might be preferable for groups of relatively well-functioning adults. 
Table 1: Needs of caregivers $(\mathrm{N}=14)$

\begin{tabular}{|l|c|c|c|c|}
\hline \multicolumn{1}{|c|}{ NEED } & $\begin{array}{c}\text { DEFINITELY } \\
\text { YES }\end{array}$ & YES & NO & $\begin{array}{c}\text { DEFINITELY } \\
\text { NO }\end{array}$ \\
\hline To improve my self-image & $7(50.0)$ & $7(50.0)$ & 0 & 0 \\
\hline To become more self-assertive & $9(64.3)$ & $5(35.7)$ & 0 & 0 \\
\hline $\begin{array}{l}\text { To communicate better with the } \\
\text { client }\end{array}$ & $11(78.6)$ & $3(21.4)$ & 0 & 0 \\
\hline $\begin{array}{l}\text { To communicate better with the } \\
\text { client's family }\end{array}$ & $10(71.4)$ & $4(28.6)$ & 0 & 0 \\
\hline $\begin{array}{l}\text { To communicate better with my } \\
\text { own family }\end{array}$ & $12(85.7)$ & $2(14.3)$ & 0 & 0 \\
\hline To handle conflict situations & $11(78.6)$ & $3(21.4)$ & 0 & 0 \\
\hline $\begin{array}{l}\text { To be better informed on AIDS } \\
\text { issues }\end{array}$ & $12(85.7)$ & $2(14.3)$ & 0 & 0 \\
\hline To talk about my own feelings & $7(50.0)$ & $7(50.0)$ & 0 & 0 \\
\hline To have a support group & $12(85.7)$ & $2(14.3)$ & 0 & 0 \\
\hline
\end{tabular}

Table 2: Problems of caregivers $(\mathrm{N}=14)$

\begin{tabular}{|l|c|c|c|c|}
\hline \multicolumn{1}{|c|}{ PROBLEM } & $\begin{array}{c}\text { DEFINITELY } \\
\text { YES }\end{array}$ & YES & NO & $\begin{array}{c}\text { DEFINITELY } \\
\text { NO }\end{array}$ \\
\hline I feel incapable of doing my work & $2(14.3)$ & 0 & $3(21.4)$ & $9(64.3)$ \\
\hline $\begin{array}{l}\text { I receive insufficient support from } \\
\text { health care facilities }\end{array}$ & $6(42.9)$ & $5(35.7)$ & $2(14.3)$ & $1(7.1)$ \\
\hline I have health problems & $2(14.3)$ & $1(7.1)$ & $4(28.6)$ & $7(50.0)$ \\
\hline I sometimes feel depressed & $10(71.4)$ & $1(7.1)$ & $2(14.3)$ & $1(7.1)$ \\
\hline My family dislikes my work & 0 & $1(7.1)$ & $6(42.9)$ & $7(50.0)$ \\
\hline I work long hours & 0 & $2(14.3)$ & $4(28.6)$ & $8(57.1)$ \\
\hline $\begin{array}{l}\text { It is difficult to be a caregiver and } \\
\text { to run my own household }\end{array}$ & $1(7.1)$ & $1(7.1)$ & $3(21.4)$ & $9(64.3)$ \\
\hline I have transport problems & $5(35.7)$ & $1(7.1)$ & $7(50.0)$ & $1(7.1)$ \\
\hline My income is insufficient & $10(71.4)$ & $4(28.6)$ & 0 & 0 \\
\hline $\begin{array}{l}\text { I have inadequate equipment for } \\
\text { caring }\end{array}$ & $5(35.0)$ & $3(21.4)$ & $5(35.7)$ & $1(7.1)$ \\
\hline
\end{tabular}

This two-hour period is long enough to allow some intensive work, yet not so long that fatigue sets in.

In order to facilitate the members' sense of group identity and continuity, the group meetings were held in the church on each occasion. Members sat on chairs placed in a circle to maximise communication. Corey (2000:92) mentions the following in this regard: "Privacy, a certain degree of attractiveness and a place that allows for face-to-face interaction is crucial". 
The two researchers travelled to the church by car, but most of the participants lived within walking distance of the church. The members were not required to make any financial contribution.

\section{THE GROUP WORK PROCESS}

It takes time for a collection of people to develop into a group that becomes an instrument through which its members may achieve positive gains. As a group develops, differences occur in the behaviour of the members and in the structure and functioning of the group. Although change in any group is a continuous, dynamic process, it is useful to think of a group as moving through a number of phases or stages in a life cycle. The identification of phases in a group's development enables a worker to ascertain where a group is regarding its development and what needs to be done to help it move toward the achievement of its aims and goals (Northen, 1988:173). The group work process has a vertical and a horisontal approach, which respectively comprise the components and the phases. The components include motivation, structuring, climate, norms, control, cohesion, relationships and programme planning, while the phases include the preparation, beginning, exploration, utilisation and termination phases (Du Preez, 1986:131; Gazda, Ginter \& Horne, 2001:50-52; Jacobs, Masson \& Harville, 2002:29-31; Toseland \& Rivas, 2005:88-93).

\section{The Preparation Phase}

In order to ensure that people are served effectively, sound preparation is essential for the initiation and subsequent development of a group. It is useful for group workers to meet potential members before the group begins (Toseland \& Rivas, 1998:154). The members may be suspicious or confused about the group's purpose, the roles that the worker will adopt, and the nature of the participation expected of them. The caregivers were met informally at the church and the purpose of the programme together with its content were briefly explained to them. They had the opportunity to explore their reservations before deciding whether to join.

\section{The Beginning Phase}

The primary task of the group worker during this early phase is to help a group to form - a group that will be beneficial to its members (Northen, 1988: 184). The members were familiar with each other, as they were from the same church. The workers conveyed to the members their willingness to involve themselves openly and spontaneously within their roles as helping persons. The members were asked what their expectations of the group were and it was written down on a sheet of paper. Using this as a starting point the aims and topics of the proposed programme were discussed. The members were asked whether they agreed with the aims and the various topics, and whether they wanted to amend anything. Each member also had the opportunity to identify her own goals. It was important that each member was clear about her place in the group, and that she was motivated to use the group to enhance her social functioning. The group functioned in a structured manner with systematic and time-limited activities (Toseland \& Rivas, 1998:240).

\section{The Exploration Phase}

During this phase the interaction is characterised by the exploration of their own life situations and their involvement in the helping process (Du Preez, 1986:158). The members became aware of similarities and differences among them, but were willing to accept each other sufficiently to continue together. The real motivation of the members became evident and the members became more relaxed and were more prepared to participate freely in the discussions.

\section{The Utilisation Phase}

During this phase the group is a cohesive one in which the members engage in a process of mutual aid and use that process as a vehicle for work on personal, interpersonal, and environmental problems. The members were now focused on accomplishing the objectives of the group. Individual members were overcoming obstacles to goal achievement in their own lives (Toseland \& Rivas, 1998:235). Strong identification with the group workers and each other took place and feelings of trust and mutual acceptance provided powerful motivation for continuing interaction in the group.

\section{The Termination Phase}

The members must separate from the group and transfer their learning to life situations outside the group 
(Anderson, 1997:121). Members are ready for termination when most of their aims are met, members talk about the changes that have occurred in their lives, structuring is more lenient, group members are very spontaneous and members are more inclined to have relationships outside the group (Du Preez, 1986:160; Strydom, 2002:137). The members knew from the beginning that there would be eight meetings. They realised that the aims of the programme were met and that they had been empowered to meet the challenges as caregivers. It was important in this last phase that the members and the workers were evaluated, that feelings of departure were discussed and that the closing session was made special.

A generalised summary of the group work process as it was manifested in this research study is given in Appendix D.

Rules for the group workers and methods of teaching are Appendix $B$ and $C$ respectively.

\section{AIMS OF THE GROUP WORK PRO- GRAMME}

The following aims of the programme were formalised:

- Teaching them the importance of co-operation, trust and loyalty among each other, so that as a team they can work together to enhance each other's lives.

- Helping them to gain self-knowledge through self-examination.

- Enhancing their self-esteem to enable them to express feelings and opinions in a manner that respects both their own and others' rights.

- Equipping them with interpersonal skills in order to develop and maintain successful relationships.

- Providing techniques for handling conflict and managing stress.

- Providing education on care-giving and helping with actions for resolving care-giving problems.

- Teaching them the essential characteristics of relationships with people living with AIDS.

\section{CONTENT OF THE PROGRAMME}

An overview of the topics discussed, along with an indication of the programme media and content of the ses- sions are given in Table 3.

Following is a more detailed description of the content of the different sessions:

\section{Preparation}

The group workers met the caregivers. A brief outline of the proposed programme was given, and the caregivers were motivated to become involved in the programme.

\section{Session One: Orientation}

The members introduced themselves and name tags were written. Identifying particulars of the members were taken and the register marked. The members completed questionnaires. They were then asked what they expected from the group, and their thoughts and expectations were written down on a clip-board. Using bricks to demonstrate, the members were taught the importance of co-operation, trust and loyalty among one another so that they could work together as a team to enhance one another's lives. The aims and content of the programme was discussed so that any uncertainties could be sorted out. The group decided where, when and how often the group sessions should occur.

The group members had to sign group work contracts during the first meeting. A group work contract is a form of explicit agreement between the group worker and the members, and designed to clarify the position, needs and expectations of all those involved. Some element of mutual agreement must be clearly acknowledged, as must the accountability to one another of the party's concerned (Corey, 2000:367). A group work contract, which was signed by the members and the group workers, can be seen as Appendix A.

\section{Session Two: Self-knowledge}

The group discussed the importance of knowing oneself (Robertson \& Simons, 1989:135). The members made a collage of their current situation. Referring to the collage, they spoke about their likes and dislikes, their strengths and weaknesses. Every group member had to say how she would like to be in the near future. 
Table 3: An overview of the programme

\begin{tabular}{|c|c|c|}
\hline TOPIC OF SESSION & PROGRAMME MEDIA & CONTENT \\
\hline Preparation & Group discussion & $\begin{array}{l}\text { Group workers meet group } \\
\text { members } \\
\text { Obtaining permission for the } \\
\text { group work } \\
\text { Discussing programme }\end{array}$ \\
\hline 1. Orientation & $\begin{array}{l}\text { Group discussion } \\
\text { Completing questionnaires } \\
\text { Marking register } \\
\text { Signing contracts }\end{array}$ & $\begin{array}{l}\text { Getting to know one another } \\
\text { Importance of teamwork } \\
\text { Administrative aspects }\end{array}$ \\
\hline 2. Self-knowledge & $\begin{array}{l}\text { Group discussion } \\
\text { Making a collage }\end{array}$ & Self-examination \\
\hline 3. Self-esteem & Group discussion & $\begin{array}{l}\text { Enhancement of self-esteem } \\
\text { Becoming self-assertive } \\
\text { Developing leadership qualities }\end{array}$ \\
\hline 4. Communication & $\begin{array}{l}\text { Group discussion } \\
\text { Demonstration of } \\
\text { communication skills. }\end{array}$ & $\begin{array}{l}\text { Effective communication } \\
\text { Learning interpersonal skills } \\
\text { Talking and listening }\end{array}$ \\
\hline $\begin{array}{l}\text { 5. Handling conflict and } \\
\text { stress }\end{array}$ & $\begin{array}{l}\text { Group discussion } \\
\text { Case studies } \\
\text { Stress exercises }\end{array}$ & $\begin{array}{l}\text { Develop negotiating skills } \\
\text { Win-win situation } \\
\text { Management of stress }\end{array}$ \\
\hline 6. Role of the caregiver & $\begin{array}{l}\text { Group discussion } \\
\text { Role-play }\end{array}$ & $\begin{array}{l}\text { Tasks and functions of } \\
\text { caregivers } \\
\text { Qualities of caregivers } \\
\text { Needs and problems }\end{array}$ \\
\hline $\begin{array}{l}\text { 7. Relationship with the } \\
\text { patient and his/her } \\
\text { family members }\end{array}$ & $\begin{array}{l}\text { Group discussion } \\
\text { Story-telling }\end{array}$ & $\begin{array}{l}\text { Healthy relationship } \\
\text { Support of the family } \\
\text { Bereavement counselling }\end{array}$ \\
\hline 8. Closing session & $\begin{array}{l}\text { Group discussion } \\
\text { Completing questionnaires } \\
\text { Handing out certificates } \\
\text { Farewell party }\end{array}$ & $\begin{array}{l}\text { Summary } \\
\text { Evaluation }\end{array}$ \\
\hline
\end{tabular}

\section{Session Three: Self-esteem}

The group discussed the meaning of self-esteem, referring to the difference between a low and a healthy self-esteem. Factors, such as physical appearance, intelligence, background and friendship that influence self-esteem, were discussed. Ways in which the selfesteem could be improved, were discussed (Strydom, 2002:216-220). The group workers explained the difference between passive, self-assertive and aggressive 
behaviour, and encouraged the members to be self-assertive (Cournoyer, 1996:38). Leadership qualities were discussed and the members were asked to evaluate their own leadership qualities (Keech, 1987:13). The members discussed ways in which they could improve their self-esteem and leadership qualities, and of becoming more self-assertive.

\section{Session Four: Communication}

The members played the game of 'telephone' to illustrate communication. The group discussed effective and ineffective means of communication (Wessels, 2003:155-161). The best ways of talking and listening were discussed (Hopson \& Scally, 1984:94-95; Kroon, 2000:253). Every member had to demonstrate her skills in communication with a partner. To illustrate their observation skills, two members had to sit back to back while writing down what each other's clothes and accessories looked like. Feedback was given.

\section{Session Five: Handling conflict and stress}

The group members thought about different conflict situations which occurred in their lives. The different conflict styles were then discussed, namely to ignore the problem; to react tit for tat; the win-lose situation and the win-win situation. The first three styles were not ideal, as there was an absence of good communication, which could lead to feelings of anger and depression. The win-win situation was then discussed with emphasis on listening, the 'l' message, giving both parties time to talk, evaluating strengths and weaknesses of the solutions and implementing the best solution.

The group was given a few case studies where conflict situations were present and instructed to practise the win-win situation. The nature and origin of stress was discussed. Exercises were done in the group to alleviate stress including holding one's breath, pointing toes, clenching fists and tightening arm muscles and then releasing

\section{Session Six: Role of the caregiver}

The tasks and functions of a caregiver were discussed. Basic nursing care, helping with domestic chores, counselling the person living with AIDS, bereavement coun- selling, giving practical advice about nutrition, hygiene and preventive care, and liaising between the health and welfare services and the people living with AIDS were dealt with. The qualities that caregivers should possess were also discussed. They included being a good listener, being non-judgemental, being empathetic, being committed, being trustworthy, being self-confident and getting along easily with people (Oleske \& Czarniecki, 1999:129). The needs and problems of caregivers were dealt with. Role-play was used to illustrate how the problems could be solved.

\section{Session Seven: Relationship with the per- son living with AIDS and his/her family members}

The characteristics of a healthy relationship were discussed. The group looked at some of the feelings, like denial, shock, anger, bargaining, depression, loneliness and fear, which the person living with AIDS and family experience when they learn that the person is HIV-positive. Ways in which the caregivers can support the family were dealt with (Rait, Ross \& Rao, 1997:229-231). In order to help the person living with AIDS and family to deal with the phenomenon of HIVIAIDS, the story-telling technique could be used, for example, a story can be told of young people who have sexual relationships, become infected and then become ill. The caregivers were instructed in bereavement counselling (Wessels, 2003:187-189).

\section{Session Eight: Closing session}

Every member completed the questionnaire for the after-measurement. The most important elements of every session were summarised and evaluated. It had to be determined whether the members' expectations were met. Certificates and photographs were handed out. A farewell party was enjoyed.

\section{EVALUATION OF THE PROGRAMME}

\section{Measurement by the single system}

The participants completed questionnaires before the programme commenced and then again after the presentation of the programme The questionnaire was designed to ascertain the level of wellness and competency of caregivers. The questionnaire was divided into 
five sections, which corresponded with the contents of the different sessions. The sections (constructs) were self-esteem (C1), self-assertiveness (C2), communication (C3), competency as caregiver (C4) and competency as family member (C5). Using the Likert format (Rubin \& Babbie, 2001:230), the participants in the research were presented with 25 statements in the questionnaire and then asked to answer according to a fivepoint scale. The scale could be seen as follows: $5=$ strongly agree; 4 = agree; 3 = neutral; 2 = disagree and 1 = strongly disagree. Every participant's scores for the different sections were added, and the two measurements were compared. A higher score during the after measurement would indicate an improvement.

\section{Validity and reliablility}

Confirmatory factor analyses were done on all five of the constructs to determine the validity. Cronbach Alpha coefficients were calculated on the constructs to determine the reliability of the constructs (Anastasi, 1988:817). A construct was considered to be reliable if the Cronbach Alpha coefficient was bigger than 0.5 (Table 4).

The natural measurement to consider when interpreting any differences is called the standardised difference. In other words, it is the difference between the two means divided by the standard deviation. Let $\mu_{1}$ and $\mu_{2}$ represent the means of two populations, while ó represents the standard deviation. The standard difference (ä) is as follows:

$$
\begin{aligned}
& \delta=\frac{\mu_{1}-\mu_{2}}{\Sigma} \text { or } \\
& \delta=\frac{\operatorname{Mean}_{\mathrm{a}}-\operatorname{Mean}_{\mathrm{b}}}{\operatorname{Max}\left(\mathrm{Std}_{\mathrm{a}} ; \mathrm{Std}_{\mathrm{b}}\right)}
\end{aligned}
$$

This value (ä) is also known as the effect size of the difference in population means. Cohen (1988) and Steyn (1999:3) provide the following guidelines for the interpretation of the results:

- $\quad \quad \quad a=0,2:$ small effect, which means that if it was new research, the experiment or research study should rather be repeated in order to make sure that there is an effect. In other research such a result would not be considered as significant.

- $\quad$ ä = 0,5: medium effect, which can be observed and can indicate a significance. A better planned experiment or research study may provide a more significant result.

- $\quad$ ä $>0,8$ : large effect, which means that the results are significant and of practical value. Remember that ä can also be negative as $\mu_{1}<\mu_{1}$. Therefore the guidelines apply to the absolute value of ä.

According to Table 5 there was an improvement in the way they felt about themselves in all the areas. The greatest improvement could be seen in the sections on self-esteem (C1) and communication (C3). This could be attributed to the fact that they felt more empowered after the completion of the programme. There was a medium effect on self-assertiveness (C2) and competency as a caregiver (C4). The least improvement was in the section on their relationships with their families (C5). This could be due to the fact that the caregivers' were satisfied with their relationships from the beginning.

\section{Measurement by means of an evaluation questionnaire}

At the final session, the caregivers were asked to evaluate the programme according to the following four ques-

Table 4: Validity and reliability

\begin{tabular}{|l|c|c|c|l|}
\hline \multicolumn{1}{|c|}{ Construct } & $\begin{array}{c}\text { Cronbach } \\
\text { Alpha }\end{array}$ & $\begin{array}{c}\text { Number of } \\
\text { factors } \\
\text { retained }\end{array}$ & $\begin{array}{c}\text { Percentage } \\
\text { variance } \\
\text { explained }\end{array}$ & Communalities \\
\hline C1 & 0.77 & 2 & 89.46 & $83.17-97.54$ \\
\hline C2 & 0.62 & 1 & 59.09 & $46.05-68.67$ \\
\hline C3 & 0.75 & 1 & 58.37 & $38.08-72.90$ \\
\hline C4 & 0.60 & 1 & 51.66 & $36.70-69.73$ \\
\hline C5 & 0.56 & 2 & 81.70 & $78.34-84.07$ \\
\hline
\end{tabular}


Table 5: ä - Values to determine differences between pre- and post-tests

\begin{tabular}{|c|c|c|c|c|}
\hline Construct & $\mathbf{N}$ & Mean & ST D & $\delta$-value \\
\hline C1 Pre & 14 & 4.13 & 0.61 & \multirow{2}{*}{1.08 ** } \\
\hline C1 Post & 14 & 4.79 & 0.38 & \\
\hline C2 Pre & 14 & 3.83 & 0.89 & \multirow{2}{*}{0.67 * } \\
\hline C2 Post & 14 & 4.43 & 0.62 & \\
\hline C3 Pre & 14 & 4.18 & 0.66 & \multirow{2}{*}{$1.03^{* *}$} \\
\hline C3 Post & 14 & 4.86 & 0.21 & \\
\hline C4 Pre & 14 & 4.25 & 0.56 & \multirow{2}{*}{0.70 * } \\
\hline C4 Post & 14 & 4.64 & 0.45 & \\
\hline C5 Pre & 14 & 4.55 & 0.71 & \multirow{2}{*}{0.31} \\
\hline C5 Post & 14 & 4.77 & 0.49 & \\
\hline Large & & & & \\
\hline Mediun & & & & \\
\hline
\end{tabular}

tions:

- What did you learn from the programme?

- Self-control. (2)

- I feel motivated to do my work as caregiver. (4)

- I learned about myself - what kind of person I am. (3)

- I learned to accept myself and feel more confident. (3)

- I learned to communicate better. (8)

- Ilearned to observe better.

- l learned about good manners.

- I learned to handle conflict. (6)

- I learned how to deal with stress. (3)

- I learned to listen to people.

- I learned to take care of people living with AIDS. (10)

- Ilearned how to protect myself when working with a person living with AIDS.

- I I am not afraid of the person living with AIDS anymore.

- Ilearned to be punctual.

- I learned more about the role of the social worker.

- What were the positive aspects of the programme?

- We were one happy family.

- We learned to work as a team. (3)
- We learned to respect and like each other, as we did not respect each other before. (6)

- We learned to understand each other better. (4)

- We were empowered. (2)

- I liked the story-telling technique. (4)

- We could understand the sessions.

- We liked the refreshments at the end of the sessions.

- $\quad$ The researchers were very nice. (2)

- What were the negative aspects of the programme?

- I sometimes felt tired during the sessions.

- What would you add or change to the programme?

- I would like to attend another course.

- I would like more information on the protection of caregivers.

- I would welcome more knowledge on how to counsel and debrief people. (3)

\section{DISCUSSION}

According to the results of the single system measurement as well as the evaluation questionnaire, all the aims of the programme were met. The group process 
provided the caregivers the opportunity to work as a team, and to share their needs and problems. The programme promoted a sense of personal competence. The sessions on self-knowledge and self-esteem helped the caregivers to identify their strengths and weaknesses, and feel good about themselves. Role-play and the discussions on case studies helped them to communicate better. They are now able to handle conflict situations and manage stress as they were taught techniques in this regard.

They were also helped to develop the required knowledge base as they received information on various aspects of care-giving. The session on relationships gave them more confidence to deal with the people living with AIDS and their families. It was important for them to realise that they were equipped as caregivers and that they were doing valuable work.

Although the researchers and the caregivers communicated well, the language and culture differences did play a role. Tswana-speaking social workers could have made a greater impact on the Black caregivers. Another limitation that could be mentioned was that the programme did not include information on HIVIAIDS.

\section{LIMITATIONS OF THE STUDY}

The following limitations were found in the study:

- The group members were Tswana-speaking and although they could all speak and understand English, there was evidence of a language barrier, especially with regard to difficult terminology.

- The research was conducted with 14 caregivers and therefore the results might not be generalisable to all caregivers.

- There was no control group to determine whether the difference in measurement could be attributed to the programme.

\section{CONCLUSION}

As the HIVIAIDS epidemic matures in South Africa, overwhelming the capacity of the health services to cope, the responsibility of care for people living with AIDS is increasingly borne by caregivers. These caregivers are often over-worked, suffer from stress and do not receive recognition for their work. It was obvious that strategies should be employed to ensure that caregivers were encouraged to do their work to the best of their ability. One way in which they could be supported and empowered was by presenting a group work programme.

In this study, the programme was presented to 14 caregivers for eight consecutive weeks. The themes of the eight sessions were orientation, self-knowledge, selfesteem, communication, handling conflict and stress, role of the caregiver, relationship with the person living with AIDS and his/her family members and the closing session.

From the results of the study, it was obvious that this group experience facilitated more effective problem solving, helped them to achieve a greater measure of control over their own lives, improved their social support and ultimately reduced the negative consequences associated with care giving in a cost-effective and efficient manner.

\section{RECOMMENDATIONS}

The following recommendations can be suggested:

- The group worker must possess good communication skills in order to explain some matters repeatedly and in lay terms. It is very important especially if there is a culture and language barrier between the group workers and the members.

- A variety of teaching aids should be utilised during every session to keep members involved and motivated for subsequent sessions.

- A session could also be included on knowledge of HIVIAIDS.

- Further research is needed on the requirements of people living with AIDS and expectancies from caregivers.

- Research is also needed to find ways of recognising and supporting caregivers in their work.

\section{LIST OF REFERENCES}

ANASTASI, A 1988: Psychological testing. New York: Macmillan. ANDERSON, J 1997: Social work with groups: A process model. Cape Town: Prentice-Hall.

ANON 2002: Perception of empowerment by family caregivers of patients with a terminal illness. International Journal of Palliative Nursing, 8(3):142

ARNO, PS; LEVINE, C; \& MEMMOTT, MM 1999: The economic value 
of informal care giving. Health Affairs, 18:182-188.

BABBIE, E 2001: The practice of social research. London: Wadsworth.

BALETA, A 2002: World Summit opens with call to protect the poor and the environment. Lancet, 360(3):699.

BEBBINGTON, AC \& GATTER, PN 1994: Volunteers in an HIV social care organisation. AIDS Care, 6(5):571-586.

BLOOM, M; FISCHER, J \& ORME, JG 1999: Evaluating practice: guidelines for the accountable professional. London: Allyn \& Bacon.

COHEN, J 1988: Statistical power analysis for the behavioural sciences. Hillside, New Jersey: Erlbaum.

COREY, G 2000: Theory and practice of group counselling. Pacific Grove: Brooks/Cole.

COREY, MS \& COREY, G 2002: Groups: Process and practice. Pacific Grove: Brooks/Cole.

COURNOYER, B 1996: The social work skills book. Boston: Brooks/ Cole.

DEPARTMENT OF HEALTH 2002: Summary Report: National HIV and syphilis antenatal sero-prevalence survey in South Africa 2002. Pretoria: Government Printers.

DE VOS, AS; STRYDOM, H; FOUCHE, CB \& DELPORT, CSL 2005 : Research at grass roots: For the social sciences and human service professions. Pretoria: Van Schaik.

DU PREEZ, MSE 1986: Maatskaplike groepwerk: Teorie en praktyk. (Social group work: theory and practice). Johannesburg: Keartland Press.

EVIAN, C 2000: Primary AIDS care: A practical guide for primary health care personnel in the clinical and supportive care of people with HIVIAIDS. Johannesburg: Jacana Education.

GARVIN, CD 1997: Contemporary group work. London: Allyn \& Bacon.

GAZDA, GM; GINTER, EJ \& HORNE, AM 2001: Group counselling and group psychotherapy: Theory and application. Boston: Allyn $\&$ Bacon.

GOICOECHEA-BALBONA, A 1998: Children with HIVIAIDS and their families: A successful social work intervention based on the culturally specific health care model. Health and Social Work, 23(1):61-70.

GRABBE, L \& DEMI, AS 1995: Functional status and the use of formal home care in the year before death. Journal of Aging and Health, 7(3):339-365.

GUTIERREZ, L 1990: Working with women of color: An empowerment perspective. Social Work, 35(1):149-154.

HOPSON, B \& SCALLY, M 1984: Lifeskills teaching programmes. No. 1. Leeds: Leeds University Printing Services.

HUNT, B 1996: HIVIAIDS training in CACREP-approved counsellor education programs. Journal of Counseling and Development, 74(3):295-300.
JACOBS, EE; MASSON, RL \& HARVILLE, RL 2002: Group counselling: Strategies and skills. Pacific Grove: Brooks/Cole-Thomson Learning.

KEECH, R 1987: Education for living: A programme for developing self-knowledge and personal relationships. Johannesburg: Divaris Stein Publishers

KROON, S 2000: Die ontwikkeling van entrepreneursgerigte ouerskapvaardighede: Die taak van die maatskaplike werker. (The development of entrepreneurial based parent skills: The role of the social worker). Potchefstroom: North-West University. (Unpublished PhD Thesis).

LEE, J 1994: The empowerment approach to social work practice. New York: Columbia University Press.

MULLEN, JT 1998: Aging and informal care giving to people with HIVIAIDS. Research on Aging, 20(6):712-739.

NATIONAL RESEARCH FOUNDATION 2004: Guide 2005. The NRF focus area programme. Available at: www.nrf.ac.za. (Date of access: 2 April 2004).

NEUMAN, WL 2000: Social research methods: Qualitative and quantitative approaches. London: Allyn \& Bacon.

NEW DICTIONARY OF SOCIAL WORK 1995: Cape Town: CTP Book Printers

NEW ENGLISH USAGE DICTIONARY 1995: London: Hodder \& Stoughton.

NORTHEN, H 1988: Social work with groups. New York: Columbia University Press.

O'CONNOR, DL 2002: Toward empowerment: Re visioning family support groups. Social Work with Groups, 25(4):37-56.

OLESKE, JM \& CZARNIECKI, L 1999: Continuum of palliative care Lessons from caring for children infected with HIV-1. Lancet 354(9186):1287-1293.

PEAK, T; TOSELAND, R \& BANKS, S 1995: The impact of a spousecaregiver support group on care recipient health care costs. Journal of Aging and Health, 7(3):427-449.

RAIT, DS; ROSS, JM \& RAO, SM 1997: Treating couples and families with HIV: A systematic approach. (In: Yalam, ID ed. 1997 Treating the psychological consequences of HIV. San Francisco: Jossey-Bass Publishers, pp 225-263).

ROBERTSON, JF \& SIMONS, RL 1989: Family factors, self-esteem, and adolescent depression. Journal of Marriage and the Family, 51(1):125-138.

ROSS, E 2001: Images of AIDS: Psychosocial issues for affected individuals, families and professional caregivers. Social Work Practitioner-Researcher, 13(2):20-32.

RUBIN, A \& BABBIE, E 2001: Research methods for social work Belmont: Wadsworth.

SCHULZ, R; O'BRIEN, A; BOOKWALA, J \& FLEISSNER, K 1995 Psychiatric and physical morbidity effects of dementia care giving: Prevalence, correlates and causes. Gerontologist, 
35(6):771-791.

SCHULZ, R; VISINTAINER, P \& WILLIAMSON, GM 1990: Psychiatric and physical morbidity effects on care giving. Journal of Gerontology Psychological Sciences, 45(5):181-191.

SKWEYIYA, Z 2003: The need for greater support of community efforts to protect children. Pretoria: Ministry of Social Development.

STAPLES, LH 1990: Powerful ideas about empowerment. Administration in Social Work, 14(2):29-42.

STEYN, HS 1999: Praktiese beduidenheid: Die gebruik van effekgroottes. Wetenskaplike Bydraes. Reeks B: Natuurwetenskappe nr 117. Potchefstroom: Publikasiebeheerkomitee, $\mathrm{PU}$ vir $\mathrm{CHO}$.

STRYDOM, C 2002: Evaluation of an HIVIAIDS programme for students at a tertiary institution with emphasis on peer group involvement. Potchefstroom: North-West University. (Unpublished PhD Thesis).

TOSELAND, RW \& RIVAS, R 1998: Group work practice. Boston: Allyn \& Bacon.

TOSELAND, RW \& RIVAS, RF 2005: An introduction to group work practice. Boston: Allyn \& Bacon.

UNAIDS 2000: Caring for carers: Managing stress in those who care for people with HIV and AIDS. Geneva: UNAIDS.

UNAIDS 2002: HIVIAIDS human resources and sustainable development. Geneva: UNAIDS.

WESSELS, CC 2003: Die opstel en evaluering van ' $n$ maatskaplikewerk-bemagtigingsprogram vir gesinne van MIVpositiewe/VIGS-pasiënte. (The development and evaluation of a social work empowerment programme for families of HIV-positive/ AIDS patients.) Potchefstroom: North-West University. (Unpublished PhD Thesis).

WHITESIDE, A \& SUNTER, C 2000: AIDS: The challenge for South Africa. Cape Town: Human \& Rousseau.

WORLD HEALTH ORGANIZATION 2000: Fact sheets on HIVIAIDS:

A desktop reference. Geneva: World Health Organization. 


\section{APPENDIX A}

\section{THE GROUP WORK CONTRACT}

As a group member, I agree to:

1. attend each group session or call one day before the group meeting to explain my absence;

2. arrive on time for each group meeting;

3. not talk about anything that occurs in the group to anyone outside the group, unless it applies only to myself and no other group member;

4. carry out all assignments agreed to in the group between group sessions;

5. speak in turn so that everyone has an opportunity to talk;

6. participate in exercises, role-plays and other simulations conducted during group meetings; and

7. give the group two weeks' notice before terminating my participation.

As the group workers, we agree to:

1. come prepared for each group session;

2. begin and end all group sessions on time;

3. provide refreshments and programme material needed for each session;

4. discuss the group only within work context; and

5. evaluate each group session to ensure that the group is helping all members resolve their problems and is personally satisfying to all group members. 


\section{APPENDIX B}

\section{RULES FOR THE GROUP WORKERS}

In view of the use of a group to implement the programme, the observance of the following rules was regarded as being important:

- Aclimate of respect for, trust in and acknowledgement of the differences between people should prevail.

- The group worker should take time to establish good relationships in the group.

- The group members should feel safe to express themselves freely and to explore ideas without the fear of criticism and reprisal.

- The group members have the right to expect that what they say will remain confidential (Gazda et al. 2001:314).

- The group worker must be well prepared and well organised.

- The sessions should be more in the form of discussions than in that of lectures.

- The worker should not tell the group members what to do; they should be allowed to make up their own minds.

- The worker should involve the members by asking them to do certain chores, such as leading the opening, summarising the previous session or serving refreshments.

- During the sessions, the worker should refer to the aims of the session as well as to the aims of the programme.

- At the beginning of each session, there should be an opening, singing, an ice-breaker and a summary of the previous session to refresh the minds of the members.

- At the end of each session, a summary and evaluation of the session, as well as planning for the following session should take place.

- Refreshments should be provided at each session 


\section{APPENDIX C}

\section{METHODS OF TEACHING}

Many teaching methods or strategies exist to promote learning in the group, including the following:

- Visual aids: Posters, photographs, pictures, overhead projection, slide presentations, videos and works of art can all be powerful educational tools.

- Learning aids: Flip charts, fact sheets, flash cards, wall charts, drawings done by the group or others, diagrams, tables, and graphs provide clear and easy access to information.

- Group discussion: The New Dictionary of Social Work (1995:28) describes the term group discussion as follows: "Purposeful discussion under the guidance of a social worker in which all the members of the group are involved in order to promote their social functioning." Buzz groups, where two or three members discuss a topic, can encourage participation.

- Role-play: Role-play is a technique in social work whereby reality is simulated to enable the group members to develop insight, learn skills, cope with feelings and to practise, interpret and modify modes of behaviour (New Dictionary of Social Work, 1995:55). Role-play should be followed by a group discussion on the situation (Kroon, 2000:239).

- Story-telling: People like to hear about the experiences of others, and often find that they can relate to these experiences. Fictional stories are helpful in sharing important messages (World Health Organisation, 2000:9/6). An assumption underpinning a story-telling approach is that when people tell stories, they are making sense of life experiences, raising awareness of those experiences, re-evaluating life experiences as a motive for life change, and identifying personal strengths in adverse life experiences. In other words, a story-telling approach embraces elements of empowerment by fostering collaborative effort and inclusiveness (Gutierrez, 1990:152).

- Games and play: Board games, making models of clay, and puppets can be used to present important messages.

- Movement exercises: When introducing most exercises, the leader will want to inform the members of the purpose and how the exercises will be conducted (Jacobs et al. 2002:236).

- Written exercises: A group worker should always be prepared to provide the necessary writing materials such as pens, pencils and paper. When passing out any forms that are going to be completed, it is best to turn them face down until the instructions have been given fully (Jacobs et al. 2002:236).

- Homework: Homework maximises what is learned in the group and is a means of translating this learning to many different situations in daily life. Homework should be designed collaboratively with the group members (Corey \& Corey, 2002:231). 


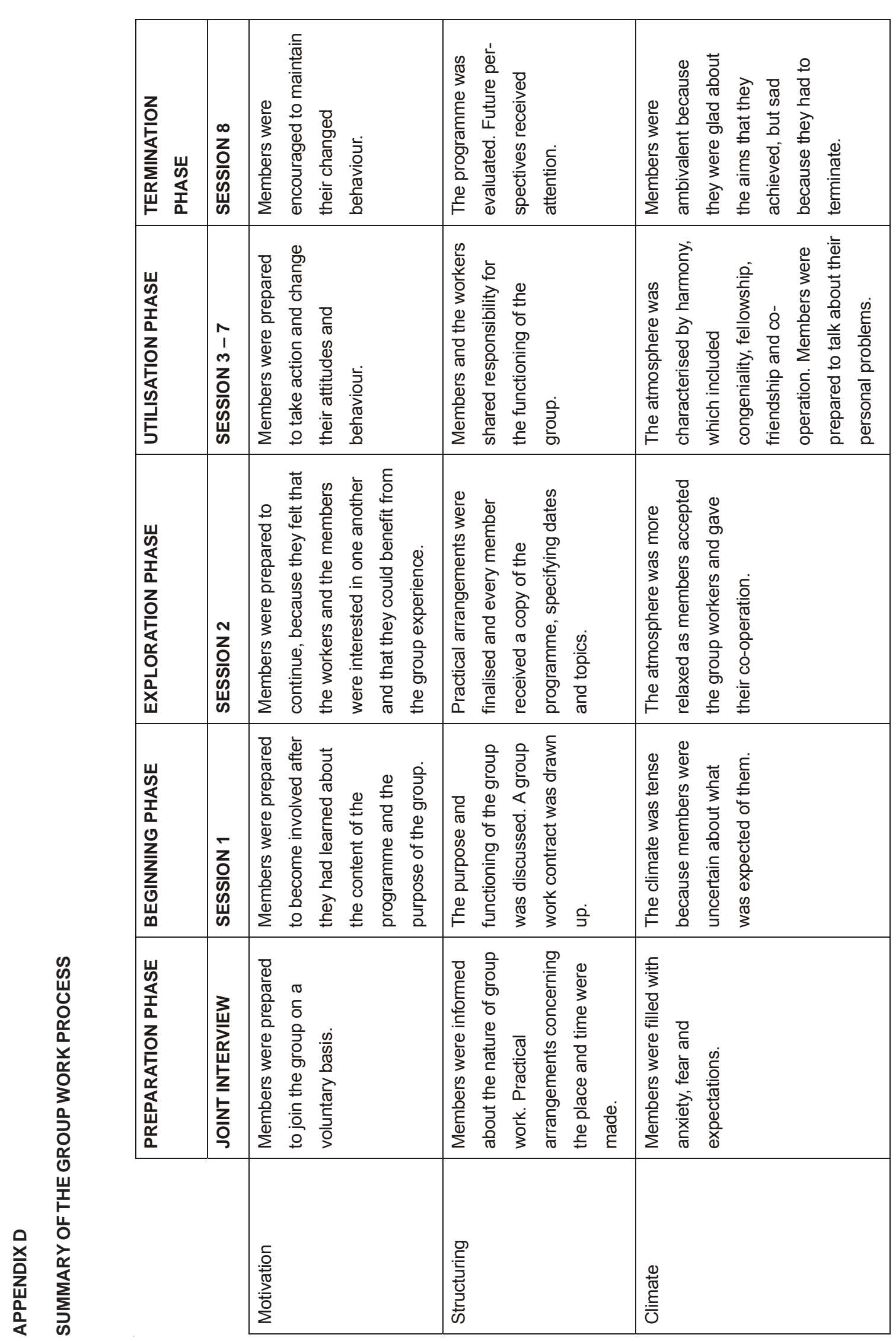




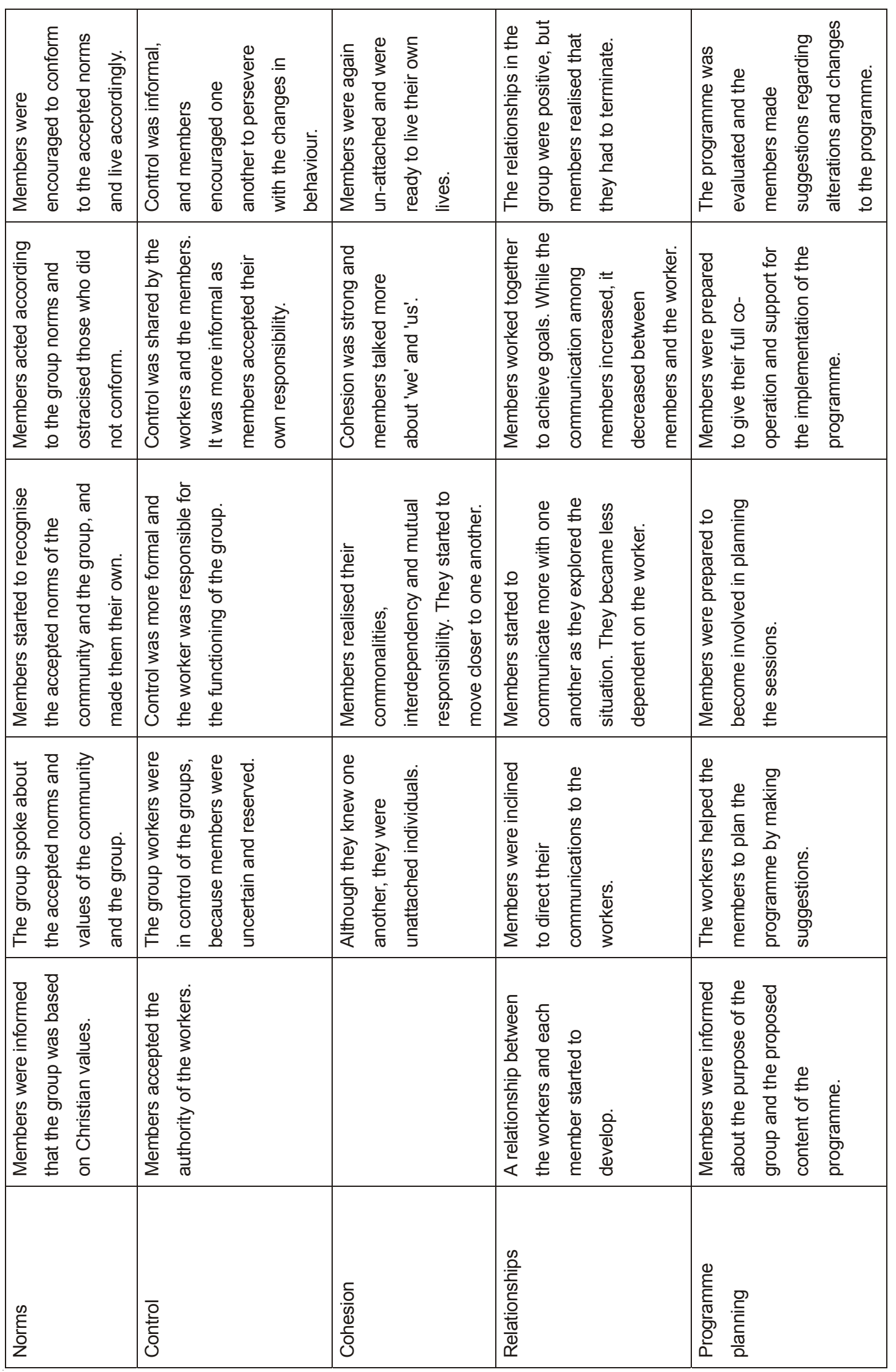

